http://dx.doi.org/10.11646/zoosymposia.13.1.13

http://zoobank.org/urn:lsid:zoobank.org:pub:2522D994-5DEB-431C-806D-5BE0A46E7367

\title{
The family Cypraeidae Rafinesque, 1815, in the northeast Pacific: One spectacular species
}

\author{
LINDSEY T. GROVES \\ Natural History Museum of Los Angeles County, Malacology Department, 900 Exposition Blvd., Los Angeles, CA 90007, USA. \\ E-mail:lgroves@nhm.org
}

\begin{abstract}
Neobernaya spadicea (Swainson, 1823) is the only representative of the family Cypraeidae in the northeast Pacific Ocean. It ranges from Monterey Bay, Monterey County, California, to southern Baja California Sur. This remarkable species is unmistakable and is unlikely to be confused with any other cypraeid.
\end{abstract}

\section{Introduction}

Of the approximately 260 species of living cowries Neobernaya spadicea (Swainson, 1823) is the only representative of the family Cypraeidae found in the entire Californian Province [= Northern Panamic Province of Lorenz (2017)]. Its southern range overlaps with the northern ranges of the Panamic species Pseudozonaria arabicula (Lamarck, 1810), P. annettae (Dall, 1909), and Naria albuginosa (Gray, 1825). This province is also known as the Mainland Panamic Province (Lorenz 2017).

\section{Materials and Methods}

One-hundred-and-fifty-one lots of Neobernaya spadicea were examined in the LACM Malacology collection and over 50 specimens from the LACMIP collection were also examined. Recent and fossil collections of Cypraeidae were examined in person at the Santa Barbara Museum of Natural History, the California Academy of Sciences, the United States National Museum of Natural History, University of California Museum of Paleontology, and the San Diego Museum of Natural History and via on-line catalogs for holdings of $N$. spadicea at the Museum of Comparative Zoology, Harvard University, and the Academy of Natural Sciences of Drexel University. Specimen photography was accomplished with a Nikon D7200 camera and Nikon Camera Control Pro2 software for iMac and figures prepared via AffinityPhoto. The radula was prepared and mounted on double-sided carbon tabs for SEM and was examination as noted by Geiger et al. (2007).

\section{Abbreviations}

CSUF California State University, Fullerton, California, USA.

DMNH Delaware Museum of Natural History, Wilmington, Delaware, USA.

LACM Natural History Museum of Los Angeles County, Malacology Department, Los Angeles, California, USA.

LACMIP Natural History Museum of Los Angeles County, Invertebrate Paleontology Department, Los Angeles, California, USA.

SBMNH Santa Barbara Museum of Natural History, Santa Barbara, California, USA.

USNM National Museum of Natural History, Smithsonian Institution, Washington, USA.

OD Original designation 


\section{Systematics}

\section{Cypraeoidea Rafinesque, 1815}

Description. Shells of large to small size, globular or elongate shaped, shell glossy, mostly smooth and bilaterally symmetrical. Aperture long, narrow, nearly straight, many times lined with denticles ("teeth") and many times extending the entire length of the ventral surface. Terminal anterior and posterior canals present. Periostracum lacking. Mantle bi-lobed, thin, contractile. Radula taenioglossate. Operculum lacking. Protoconch cancellate, concealed in mature shells.

Remarks. Cypraeoidea includes the so-called true cowries (Cypraeidae Rafinesque, 1815), egg and spindle cowries and pedicularias (Ovulidae Fleming, 1822), false cowries (Triviidae Troschel, 1863), eratos (Eratoidae Gill, 1871), and lamellarias (Velutinidae Gray, 1840). Cypraeoideans may be herbivorous, omnivorous, commensal, or predatory. Fossil record extends from the Late Jurassic to Recent.

\section{Cypraeidae Rafinesque, 1815}

Description. Shells of large to small size, usually smooth, pear-shaped, elongate, or globular; spotted, sometimes highly colorful, appearing polished. Covered by bi-lobed mantle with papillae. Aperture narrow usually with denticles ("teeth") lining labral, columellar margins. Juvenile shell (= bulla stage) (Fig. 1F-G) thin with wide aperture without denticles. Spire calloused over in mature shells. Operculum lacking. Radula taenioglossaate with central tooth (rachidian), three marginal teeth on either side. Single species in northeast Pacific.

Remarks. Cypraeids may be omnivorous, herbivorous, or predatory. These are the true cowries. Fossil record extends from Late Jurassic to Recent.

\section{Zonariinae Schilder, 1932}

Description. Shells of medium size, oblong to pyriform shape. Dorsum smooth, mostly mottled brownish colors, margins spotted within Pseudozonariini with exception of Neobernaya. Dorsal mottling present in Zonariini, some without marginal spotting.

Remarks. Includes the genera Neobernaya, and Pseudozonaria (= Pseudozonarini), and Schilderia, Zonaria and the fossil genera Proadusta and Zonarina (= Zonariini). Fossil record extends from early Oligocene to Recent.

\section{Pseudozonariini López Soriano, 2006}

Description. Originally established for an unnamed clade within Meyer's (2003: 423) compartment designated Group E and stated that "poor support along the backbone prevents me from confidently assigning names to many clades without further support and consideration of both detailed anatomical studies and fossil data." López Soriano (2006) justified the subfamilial name Pseudozonariinae not only genetically but also anatomically and to a lesser extent on shell morphology. The subfamily was reassigned to tribe level by Bouchet et al. (2017). It includes the endemic eastern Pacific genera Pseudozonaria Schilder, 1927 and Neobernaya. Fossil record extends from middle Miocene to Recent.

\section{Neobernaya Schilder, 1927}

Type species. Cypraea spadicea Swainson, 1823 (OD).

Description. Shell medium in size, elongate-pyriform, extremities produced; base, teeth white, unspotted margins. Aperture straight, anterior end wide. Fossula smooth, reduced. Columella smooth, labial lip depressed anteriorly, tapering.

Remarks. Originally described as a subgenus of Bernaya Jousseaume, 1884. Lorenz (2017) noted similarities of the $N$. spadicea fossula and that of the genus Pseudozonaria and its five living species. Because of these similarities Dolin \& Lozouet (2004) erroneously placed P. nigropunctata (Gray, 1828) in Neobernaya but their dorsal color patterns set these species apart. Fossil record from early Pliocene to Recent. Because 
Neobernaya is a basal sister to Pseudozonaria (Lorenz 2017) the two genera represent a group of west American cowries that are a conchological parallel to the European genera Zonaria Jousseaume, 1884 and Schilderia Tomlin, 1930. The morphologies are similar but the color patterns differ.

Neobernaya spadicea (Swainson, 1823)

(Figures 1, 2)

\section{Synonymy \& chresonomy}

Cypraea spadicea: Swainson, 1823a: 376.

Cypraea spadicea: Swainson, 1823b: pl. 182.

Cypraea spadicea: Reeve, 1845-1846: species 21, pl. 7, fig. 21.

Luponia spadicea: 'Gray' Carpenter, 1864: 523, 537, 657

Cypraea (Luponia) spadicea: Gabb, 1869: 78.

Cypraea spadicea: Sowerby II, 1870: 24-25, pl. 13, figs. 81-82.

Luponia spadicea: 'Gray' Keep, 1888: 59, fig. 43.

Cypraea fernandoensis: Arnold, 1907: 538, pl. 50, fig. 8-8a.

Bernaya (Neobernaya) fernandoensis: Schilder, 1927: 31, 90, 139.

Zoila (Neobernaya) spadicea: Thiele, 1931: 275.

Cypraea spadicea: Grant \& Gale, 1931: 752, pl. 27, fig. 13.

Cypraea fernandoensis: Grant \& Gale, 1931: 752.

Zonaria (Neobernaya) spadicea spadicea: Schilder, 1932: 182.

Zonaria (Neobernaya) spadicea fernandoensis: Schilder, 1932: 182.

Neobernaya spadicea: Allan, 1956: 62-63, pl. 10, figs. 17-18.

Zonaria (Neobernaya) spadicea: Schilder \& Schilder, 1971: 46.

Zonaria (Neobernaya) spadicea fernandoensis: Schilder \& Schilder, 1971: 46.

Cypraea spadicea: McLean, 1978: 39, fig. 20.5.

Cypraea spadicea: Burgess, 1985: 106, 3 unnumbered figs.

Zonaria (Neobernaya) spadicea form albinea: Raybaudi, 1984: 22 [not valid, infrasubspecific taxon].

Zonaria spadicea: Bradner \& Kay, 1989: 84, figs. 128, 131G-H.

Neobernaya spadicea: Lorenz \& Hubert, 2000: 119, pl. 60, figs. 23-27.

Neobernaya spadicea: Lorenz, 2017: 398, pl. 58.

Type material. Of Cypraea spadicea: holotype: Cabinet of London natural history auctioneer Charles Dubois (Swainson 1823a), Museum Dubois (Oldroyd 1927), current whereabouts unknown. Of Cypraea fernandoensis: holotype: USNM 164961, Pico Formation, late Pliocene, Elsmere Canyon, Newhall, Los Angeles County, California. Of Zonaria (Neobernaya) spadicea form albinea: Invalid form name assigned to specimens with white overcasts by Raybaudi (1984) in a price list, noted here for the record.

Type locality. Oc[eanus]. Pacif[icus] (Swainson 1823a). Kiener's (1844-1845) l'océan Indien is an obvious error. Burgess (1985) noted that the population center for N. spadicea seems to be in the San Diego area and perhaps a type locality in the area could be designated in the future.

Etymology. spadicis: Latin for chestnut brown.

Original description. C. testâ ovatâ, ventricosâ; dorso punctis fuscis, nebulosis, obsito; lateribus flavescentibus fusco guttatis; ventre striato, striis levatis, spadiceis. Shell ovate-oblong, unspotted; back reddish chestnut; belly white; sides livid.

Description. Shell elongate-pyriform, extremities produced. Dorsum with irregularly-shaped, chestnutbrown area with occasional flecks of white, outlined with broad band of darker brown. Fossula reduced. Margins pale blue to pale violet, unspotted. Base entirely white. (Fig. 1A-B). Color forms include rust (Fig. 1C), deep red (Fig. 1D) from specimens collected on shipwrecks off southern California (Lee 2012). Specimens with white overcasting (Fig. 1E) were discussed by Tuskes (2016). Animal with semi-translucent mantle with black, warty papillae of class $1 \mathrm{~b}$ (of Lorenz 2017). Papillae secreting black pigment when disturbed, phenomenon previously only known to Notocypraea angustata (Gmelin, 1791) (Lorenz 2017). Tentacles deep orange-red color, proboscis orange, siphonal papillae white with black base, foot creamy-white with black streaks (Fig. 2A-D). 


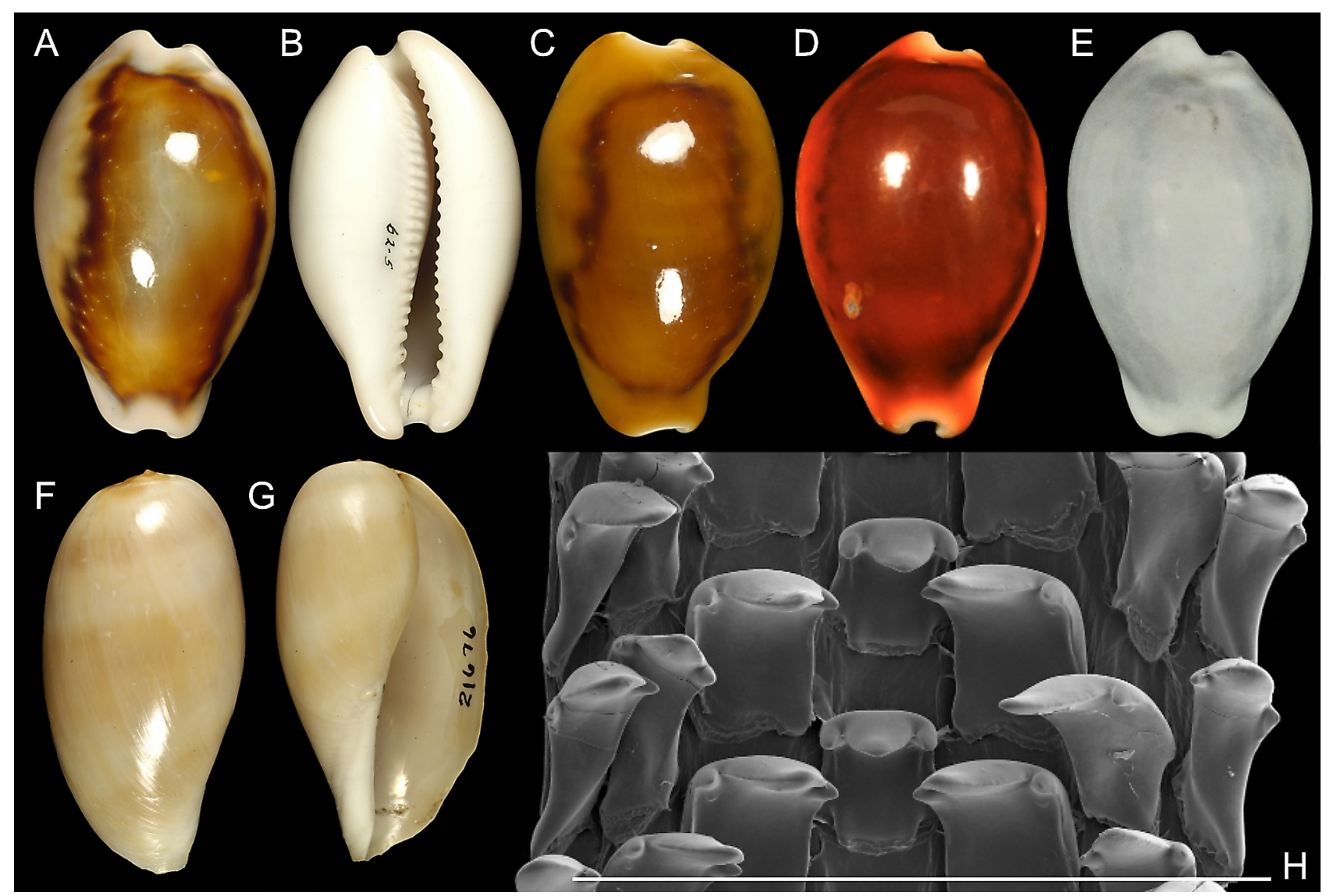

FIGURE 1. Neobernaya spadicea (Swainson, 1823). A-B. 12-24 m, N of Santa Catalina Island, California Channel Islands,

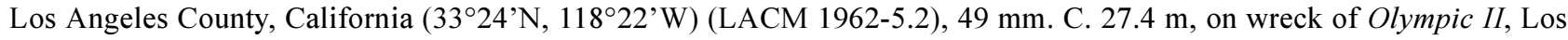
Angeles Harbor, Los Angeles County, California (LACM 152696) 36.9 mm. D. Red form, on shipwreck off Long Beach, Los Angeles County, California (Don Pisor collection, San Diego) $54.8 \mathrm{~mm}$. E. White form, off Punta Banda, Baja California (Don Pisor Collection, San Diego) 49 mm. F-G. Newport Bay, Orange County, California (LACM 156232), 36.2 mm. H. Radula from no-data specimen, SBMNH 619239, scale bar $=1 \mathrm{~mm}$.

Remarks. Neobernaya spadicea is unlikely to be confused with any other cypraeid species.

Recent Distribution. Chinatown Point (= Point Alones), Monterey Bay, Monterey County, central California, to Cedros Island, Baja California (McLean 1978), and south to "13 Fathom Spot" (2456'N, $112^{\circ} 35.5^{\prime} \mathrm{W}$ ), Baja California Sur (Jackson 2001).

Fossil Distribution (partial list). Pliocene. Towsley Formation, Towsley Canyon, Los Angeles County (Kern 1973); Pico Formation, Elsmere Canyon, near Newhall, Los Angeles County, (Arnold 1907 [as Fernando Formation], Grant \& Gale 1931, Squires et al. 2006); Pico Formation, downtown Los Angeles (Davis 1998) [as "Fernando Formation"]; San Diego Formation, San Diego County (LACMIP location 305, LACMIP location 16862 (= LACMIP location 305A), LACMIP 16817 (= LACMIP location 305C); Pleistocene: Lomita Marl, Palos Verdes Peninsula, Los Angeles County (Woodring et al. 1946); marine terraces on San Nicolas Island (Vedder \& Norris 1963); Santa Barbara Island (Ingram 1947); Newport Bay (= Palos Verdes Sand) (Kanakoff \& Emerson 1959); China Point, Baja California (Emerson 1956); Descanso Point, Baja California (Valentine 1957); Baja Point, Baja California (Emerson \& Addicott 1958); Cedros Island, Baja California, (LACMIP location 25822); Magdalena Bay, Baja California Sur (Jordan 1936). 

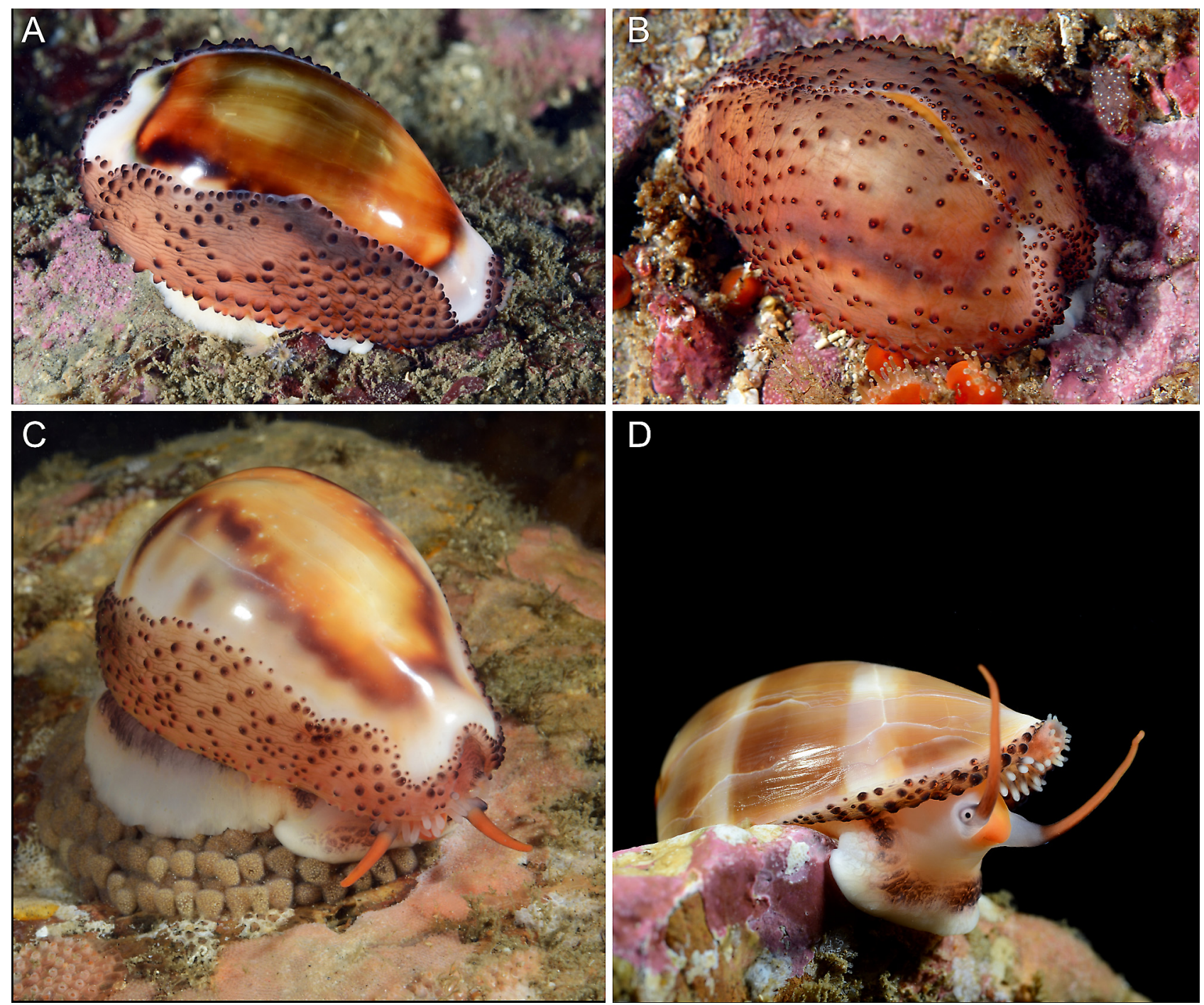

FIGURE 2. A-D. Neobernaya spadicea living animals. A. Adult with mantle partially extended. B. Adult with mantle fully extended. C. Adult female on egg cluster. D. Juvenile. All images taken at 18 m, Golf Ball Reef, off Redondo Beach, Los Angeles County, California (images courtesy of Kevin Lee, Fullerton, California).

\section{Discussion}

Neobernaya spadicea has been observed feeding on the fauna that live on the giant kelp Macrocystis pyrifera and on bryozoans and hydroids (Tuskes 2013). McGinitie \& McGinitie (1968) noted that the species is carnivorous feeding on sponges, anemones, tunicates, and molluscan eggs. Fork (1997) observed that $N$. spadicea seems to prefer the colonial ascidian Distaplia and solitary ascidian Ascidia ceratoides. Bradner \& Kay (1996) included the radula of $N$. spadicea (Fig. 1H) in their Mauritiana Pattern [model species = Mauritia mauritiana (Linnaeus, 1758)], which features a central tricuspid tooth with a pair of denticles that project below the basal platform. Tricuspid laterals are larger than the central tooth and project above the apex of the central tooth. The marginals are bladelike in profile, the inner marginal wider than the outer marginal, their bases narrow and independently attached to the radular membrane. Evans (1981) reported an unusual increase in the mortality of $N$. spadicea around Laguna Beach, Orange County, California, due to apparent predation by Octopus bimaculatus Verrill, 1883 as evidenced by drill holes predominantly on the posterior end of the base columella.

Tuskes (2013) reported female N. spadicea sitting on egg clusters in Mission Bay, San Diego County, California, and others preparing nesting sites nearby in depths of 4 and $6 \mathrm{~m}$. Several nest sites were made in valves of the Rock Scallop Crassadoma gigantea (Gray, 1825) and others were made on smooth rocks. The 
female then removes all fouling organisms from the selected surface. Mating occurred only after the site was prepared and males were attracted by the female. Three males were observed mating with a single female in laboratory conditions (Chess \& Rosenthal 1971) but this mating behavior was also observed in Mission Bay, San Diego County, California (Tuskes 2013). Eggs are laid in a circular to oval pattern between 40 to $60 \mathrm{~mm}$ in diameter and brooded by the female for about three weeks (Fork 1997). Tuskes (2013) noted that the smallest nest contained 196 egg capsules and the largest contained 296. The egg capsules vary in shape and may be oval or pyriform and measure between 2 and $2.5 \mathrm{~mm}$. The average number of embryos per capsule ranged from 865 to 1,137 (Tuskes 2013). Veligers appear to be lecithotrophic, possess a distinct propodium, and are slow swimmers with many settling quickly to the bottom (Fork 1997). Abbott \& Haderlie (1990) reported that $N$. spadicea is reproductively active in July whereas Tuskes (2013) made his observations in May. Adult size ranges between 27 and $81 \mathrm{~mm}$ in length (Lorenz 2017). Donohue (1965) erroneously reported the size range as approximately 64 to $120 \mathrm{~mm}$, which led Abbott \& Haderlie (1980) to erroneously report the maximum size as $120 \mathrm{~mm}$ as well. Donohue (1966) explained that he used incorrect scale increments on his figure thus doubling the size ranges. Unfortunately, Abbott \& Haderlie (1980) were not aware of the error. Dwarf populations exist with adult sizes under $30 \mathrm{~mm}$ (Lee 2012). Darling (1965) noted that growth is rapid in juveniles and slows considerably in adults.

Neobernaya spadicea is occasionally found in large numbers along ledges at low tide, particularly during the winter, but fairly common throughout the year in the sublittoral zone, especially under overhang rock ledges from 0 to $50 \mathrm{~m}$, under rocks. Large colonies have been observed and are active in May and June, disappeared in August and reappeared in November. Specimens have been observed living on rocks and other hard substrates, on sand, and on Zostera seagrasses (Bakus 1968). Specimens have been observed active at night and during daylight hours.

Neobernaya spadicea is a member of Meyer's (2003) Group E, which represents a second paraphyletic grade analyzed in a compartmentalized approach. Each of the genera within this group, including Pustularia, Pseudozonaria, Zonaria, Notocypraea, Cypraeovula, and Neobernaya are strongly supported as monophyletic except for Pseudozonaria. Meyer (2003) noted that $N$. spadicea is a sister taxon to Pseudozonaria and represents a northern extension of this clade both of which are exclusively eastern Pacific lineages.

\section{Acknowledgements}

Special thanks to the late James H. McLean for his encouragement and valuable insights to my research over the years ... all this despite the fact that he was not fond of cowries. Daniel L. Geiger (SBMNH) prepared the figures and extracted the radula in Fig. $1 \mathrm{H}$ and was a source of ongoing encouragement. Alex Kittle (DMNH) and Paul Valentich-Scott (SBMNH) provided information on $N$. spadicea from their respective collections. Jeff Tupen (CH2M Hill, Sacramento, CA) supplied data on N. spadicea from the Canyon Diablo area of San Luis Obispo County, California and Paul Stephens (Monterey, California) reported on its status in the Monterey Bay area. Shawn Wiedrick (CSUF) donated personally collected specimens form the remote central California coast to LACM Malacology. Kevin Lee (Fullerton, California) provided the spectacular images of live specimens. I am grateful to Don Pisor (San Diego, California) for granting permission to illustrate his magnificent specimens of red and white color forms of N. spadicea and to Paul Tuskes (San Diego, California) for the marvelous images of those specimens. Sincere thanks are given to Hugh and Arthur McLean for their generous support of this project.

\section{References}

Abbott, D.P. \& Haderlie, E.C. (1980) Prosobranchia: Marine snails. In: Morris, R.H., Abbott, D.P. \& Haderlie, E.C. (Eds). Intertidal Invertebrates of California, Stanford University Press, Stanford, California. pp. 230-307.

Allan, J. (1956) Cowry Shells of World Seas. Georgian House Pty. Ltd., Melbourne, Australia, x, 170 pp.

Arnold, R. (1907) New and characteristic species of fossils from the oil-bearing Tertiary formations of southern California. Proceedings of the United States National Museum, 32, 525-546. https://doi.org/10.5479/si.00963801.32-1545.525

Bakus, G.J. (1968) Quantitative studies on the cowries (Cypraeidae) of the Allan Hancock Foundation collection. The Veliger, 
$11,93-97$.

Bouchet, P., Rocroi, J.-P., Hausdorf, B., Kaim, A., Kano, Y., Nützel, A., Pakhaev, P., Schrödl, M. \& Strong, E.E. (2017) Revised classification, nomenclator and typification of gastropod and monoplacophoran families. Malacologia, 61, 1-526. https://doi.org/10.4002/040.061.0201

Bradner, H. \& Kay, E.A. (1996) An atlas of cowrie radulae (Mollusca: Gastropoda: Cypraeoidea: Cypraeidae). The Festivus, 28 (supplement), 1-179.

Burgess, C.M. (1985) Cowries of the World. Seacomber Publications, Cape Town, South Africa. xiv + 1-289 pp.

Carpenter, P.P. (1864) Supplementary report on the present state of our knowledge with regard to the Mollusca of the west coast of North America. British Association for the Advancement of Science, for 1863, 517-686.

Chess, J.R. \& Rosenthal, R.J. (1971) On the reproductive biology of Mitra idea (Gastropoda: Mitridae). The Veliger, 14, 172176.

Darling, S.D. (1965) Observations on the growth of Cypraea spadicea. The Veliger, 8, 14-15.

Davis, G.E. (1998) Systematic paleontology of a densely fosiliferous upper Pliocene molluscan shell lens, $6^{\text {th }}$ and Flower streets, Los Angeles, California, with commentary on the stratigraphic nomenclature of the "Fernando Formation." [MS thesis] California State University, Northridge, xvii, $235 \mathrm{pp}$.

Dolin, L. \& Lozouet, P. (2004) Nouvelles espèces de gastéropodes (Mollusca: Gastropoda) de l'Oligocène et du Miocène inférieur de l'Aquitaine. Partie 3. Cossmanniana, hores-série, 4, 1-164.

Donohue, J. (1965) Size ranges in Cypraea. The Veliger, 8, 22.

Donohue, J. (1966) Size ranges in Cypraea: Emendation. The Veliger, 8, 201.

Emerson, W.K. (1956) Pleistocene invertebrates form Punta China, Baja California, Mexico. Bulletin of the American Museum of Natural History, 111, 317-342.

Emerson, W.K. \& Addicott, W.O. (1958) Pleistocene invertebrates from Punta Baja, Baja California, Mexico. American Museum Novitates, 1909, 1-11.

Evans, R.A. (1981) Octopus predation on Cypraea spadicea. Of Sea and Shore, 12, 225-226.

Fork, S.K. (1997) Studies on development and feeding habits of the chestnut cowrie (Cypraea spadicea) [abstract]. Western Society of Malacologists Annual Report, 29, 16.

Gabb, W.M. (1869) Tertiary invertebrate fossils. Part 2. Descriptions of new species. Geological Survey of California, Palaeontology, 2, 39-63.

Geiger, D.L., Marshall, B.A., Ponder, W.F., Sasaki, T. \& Warén, A. (2007) Techniques for collecting, handling, preparing, storing and examining small molluscan specimens. Molluscan Research, 27, 1-50.

Grant, U.S., IV \& Gale, H.R. (1931) Catalogue of the marine Pliocene and Pleistocene Mollusca of California and adjacent regions. Memoirs of the San Diego Society of Natural History, 1, 1-1036.

Ingram, W.M. (1947) Fossil and Recent Cypraeidae of the western regions of the Americas. Bulletins of American Paleontology, 31, 47-125.

Jackson, J. (2001) Range extension for Cypraea spadicea Swainson, 1823. The Festivus, 33, 13-14.

Jordan, E.K. (1936) Pleistocene faunas of Magdalena Bay, Lower California. Stanford University Department of Geology Contributions, 1, 103-174.

Kanakoff, G.P. \& Emerson, W.K. (1959) Late Pleistocene invertebrates of the Newport Bay area, California. Los Angeles County Museum of Natural History Contributions in Science, 31, 1-47.

Keep, J. (1888) West Coast Shells. Samuel Carson and Company, San Francisco, California. 230 pp.

Kern, J.P. (1973) Early Pliocene marine climate and environment of the eastern Ventura Basin, southern California. University of California Publications in Geological Sciences, 96, 1-117.

Kiener, L.-C. (1844-1845) Genre porcelaine (Cypraea, Linn.). Spécies général et iconographie des coquilles vivantes, comprenant la collection du Muséum d'histoire naturelle de Paris, 1, 1-166.

Lee, J.K. (2012) Neobernaya spadicea (Swainson, 1823). Beautifulcowries Magazine, 1, 50-54.

López Soriano, J. (2006) Consideraciones taxonómicas sobre la familia Cypraeidae Rafinesque, 1815 (Mollusca: Caenogastropoda), con una nueva propuesta de clasificación supragenérica. Spira, 2, 41-62.

Lorenz, F. (2017) Cowries: A Guide to the Gastropod Family Cypraeidae. Vol. 1 - Biology and Systematics. ConchBooks, Hackenheim, Germany. 644 pp.

Lorenz, F. \& Hubert, A. (2000) A Guide to Worldwide Cowries. ${ }^{\text {nd }}$ Revised and Enlarged edition. ConchBooks, Hackenheim, Germany. 584 pp.

MacGinitie, G.E. \& MacGinitie, N. (1968) Natural History of Marine Animals, $2^{\text {nd }}$ ed. McGraw-Hill New, York. 523 pp.

McLean, J.H. (1978) Marine shells of southern California, revised edition. Natural History Museum of Los Angeles County, Science Series, 24, 1-104.

Meyer, C.P. (2003) Molecular systematics of cowries (Gastropoda: Cypraeidae) and diversification patterns in the tropics. Biological Journal of the Linnean Society, 79, 401-459. 
https://doi.org/10.1046/j.1095-8312.2003.00197.x

Oldroyd, I.S. (1927) The Marine Shells of the West Coast of North America. Stanford University Publications, University Series, Geological Sciences, 2, 301-602.

Raybaudi Massilia, L. (1987) Cypraeidae, genus Zonaria Jousseaume, 1884. The Connoisseur of Seashells, 14, 8-22.

Reeve, L.A. (1845-1846) Monograph of the genus Cypraea. Conchologia Iconica: or, Illustrations of the Shells of Molluscous Animals, 3, pls. 1-27.

Schilder, F.A. (1927) Revision der Cypraeacea (Moll., Gastr.). Archiv für Naturgeschichte, 91, 1-171.

Schilder, F.A. (1932) Cypraeacea In: Quenstedt, W. (ed.), Fossilium Catalogus 1:Animalia. W. Junk, Berlin, pp. 1-276.

Schilder, M. \& Schilder, F.A. (1971) A catalogue of living and fossil cowries. Institut Royal des Sciences Naturelles de Belgique, Mémoires, 85, 1-246.

Sowerby, G.B. II (1870) Monograph of the genus Cypraea. Thesaurus Conchyliorum or figures and descriptions of Recent shells. Privately published, London, $58 \mathrm{pp}$.

Squires, R.L., Groves, L.T. \& Smith, J.T. (2006) New information on molluscan paleontology and depositional environments of the upper Pliocene Pico Formation, Valencia area, Los Angeles County, southern California. Natural History Museum of Los Angeles County Contributions in Science, 511, 1-24.

Swainson, W. (1823a) The characters of several rare and undescribed shells. The Philosophical Magazine and Journal, 61, 375-378. https://doi.org/10.1080/14786442308644341

Swainson, W. (1823b) Zoological Illustrations or Original Figures and Descriptions of New, Rare, or Interesting Animals Selected Chiefly From the Classes of Ornithology, Entomology, and Conchology and Arranged on the Principles of Cuvier and Other Modern Zoologists. Baldwin, Cradock, and Joy, Paternoster-Row, London, 3, v-x, pls. 135-182.

Thiele, J. (1931) Handbuch der systematischen Weichtierkunde. Gustav Fischer, Jena. 778 pp.

Tuskes, P. (2013) Observation on the biology of the chestnut cowry Neobernaya spadicea in Mission Bay. The Festivus, 45 , $77-80$.

Tuskes, P. (2016) White chestnut cowry Neobernaya spadicea. The Festivus, 48, 145-147.

Valentine, J.W. (1957) Late Pleistocene faunas from the northwestern coast of Baja California, Mexico. Transactions of the San Diego Society of Natural History, 12, 289-308.

Vedder, J.G. \& Norris, R.M. (1963) Geology of San Nicolas Island, California. United States Geological Survey Professional Paper, 369, i-vi, 1-65.

https://doi.org/10.3133/pp369

Woodring, W.P., Bramlette, M.N. \& Kew, W.S.W. (1946) Geology and paleontology of Palos Verdes Hills, California. United States Geological Survey Professional Paper, 207, i-v, 1-145.

https://doi.org/10.3133/pp207 